\title{
Developing work placements in a discipline-oriented education
}

\author{
Gaute Velle ${ }^{1,2}$, Torstein Nielsen Hole ${ }^{2}$, Oddfrid Førland ${ }^{2}$, Anne-Laure Simonelli ${ }^{2}$, Vigdis \\ Vandvik $^{2}$ \\ ${ }^{1}$ Uni Research Environment, Bergen, Norway \\ ${ }^{2}$ bioCEED Centre of Excellence in Biology Education, Department of biology, University of \\ Bergen, Bergen, Norway
}

\begin{abstract}
Higher education is often divided into discipline-oriented and professional programs. Professional programs prepare students for a specific profession and include relevant theoretical and practical knowledge. Discipline-oriented programs emphasize theoretical knowledge and research within a specific discipline or field. Except for a career within research and higher education, discipline-oriented programs provide less obvious links to future careers. The transition from student life to working life may therefore be challenging.

In this paper, we present and discuss the development and implementation of a work placement course as part of the disciplinary programs in biology at the University of Bergen. The course was developed to provide students with practical- and work- related competences, to inform about opportunities for future career and to foster motivation and learning. We have revised the course according to feedback from students, workplace hosts and our experience as course teachers during the six semesters the course has been running.

The work placement course is at the bachelor (BSc) level and consists of two main components; a work placement and the student's own reporting of placement outcomes. For the placement, the students work 140 hours at a workplace as a biologist. The reporting consists of four open blog-posts, one written reflective essay and a final oral presentation. The course teachers also meet with the students and convey information on the roles of biology and biologists in today's society through a Facebook group.

Feedback from the students, hosts and course teachers point to a range of benefits from work practice in discipline-oriented study programs. Based on our experience, we provide guidance for implementing such courses.
\end{abstract}

Key words: Tacit knowledge, Blog, Higher education, Internship learning, Biology 


\section{Introduction}

Higher education is often divided into discipline-oriented and professional programs. Professional programs prepare students for a specific profession and include training in theoretical and practical skills and competences defined by the demands of the profession (Abbott, 1988). Discipline-oriented programs are linked to a specific scientific discipline, and program content and learning outcomes are generally geared towards training in theoretical and empirical aspects of the discipline, as well as in research-related skills and competences. The link to research ensures that students are exposed to the state-of-the-art knowledge within a particular domain, and these programs are therefore less sensitive to fluctuations in working life relative to professional programs. However, except for a career within research and higher education, discipline-oriented programs provide less obvious links to, and experiences aimed at, the students' future occupations. In Norway, many students in discipline programs express interest in more opportunities for practical and explicitly work-related learning activities in their curriculum (Hole et al., 2016, NOKUT, 2014). This echoes policy-makers' calls for increased workplace integration across higher education (Regjeringen, 2014, Regjeringen, 2017), and research that document positive impacts of workplace practice on motivation (Gardner and Belland, 2012, Kyndt et al., 2011), study progression (Næss et al., 2012) and learning outcomes (Kennedy et al., 2015).

In professional study programs, work placement and practice are seen as opportunities to observe and learn from the professional experts and to obtain relevant and authentic work experience (Bogo, 2006, Edwards et al., 2004), preparing the students for a professional career (Aldas et al., 2010, Simons et al., 2012). Placements may increase student's awareness of their transferable skills and foster acquisition of new transferable skills (Bennett et al., 1999, Scholz et al., 2004) In addition, work placements may promote an understanding of future careers and occupations (Matthew et al., 2012). Compared to traditional instruction, active learning methods, such as work placement, show to positively influence students' learning, achievements and knowledge retention (Freeman et al., 2014, Singer et al., 2013). Work placements tie into theory of knowledge which states that certain aspects of knowledge can only be accessed after real-life experience and execution of the activity (Dewey, 2011, Dreyfus and Dreyfus, 1986, Polanyi, 1967). Placements are a type of 'experiential learning' in that students apply their knowledge and conceptual understanding to real-world problems or authentic situations under the direction and facilitation of an instructor (Wurdinger and Carlson, 2009).

Work placements have the potential to combine opportunities for acquisition and use of disciplinary knowledge, involvement in student-active learning and exposure to authentic activities beneficial for future careers. These opportunities for enhanced learning may be untapped by solely retaining traditional teaching practices. Still, work placement training has yet to be adopted in disciplinary programs to a similar degree as in the professional study programs (Billett, 2009, Scholz et al., 2004).

We here report on the implementation of a work placement course within the biology programs at the University of Bergen that was developed to explore and exploit the potential benefits of integrating work in study programs. The placement course has now been running twice yearly for 3 years, and has evolved throughout the period in response to feedback from students, work placement hosts and discussions among the course teachers and the Norwegian Centre of Excellence in Biology Education (bioCEED). In this paper, we give an account of the development of the work placement course in biology; the background for the course, its establishment and running, and the experiences, choices and priorities made along the way. We also report on some of its reception among students. We hope the paper may provide guidance 
that can aid and motivate other higher discipline education institutions and teachers to implement work placements.

\section{Developing a work practice course within a disciplinary university department}

\subsection{The antecedents}

The idea of a work placement course in biology emerged when the Department of Biology at the University of Bergen was preparing the bioCEED Centre of Excellence application. The vision behind bioCEED is that biology (and biologists) emerge in the interplay between biological theory, the practical applications of biological knowledge and the application of biology to meet society's needs (Figure 1). Biology and biologists can be found on all sides of environmental- and ethical debates, as well as in our understanding of ourselves and the world around us. Biology education must therefore prepare our students for challenging and demanding roles in science and society.

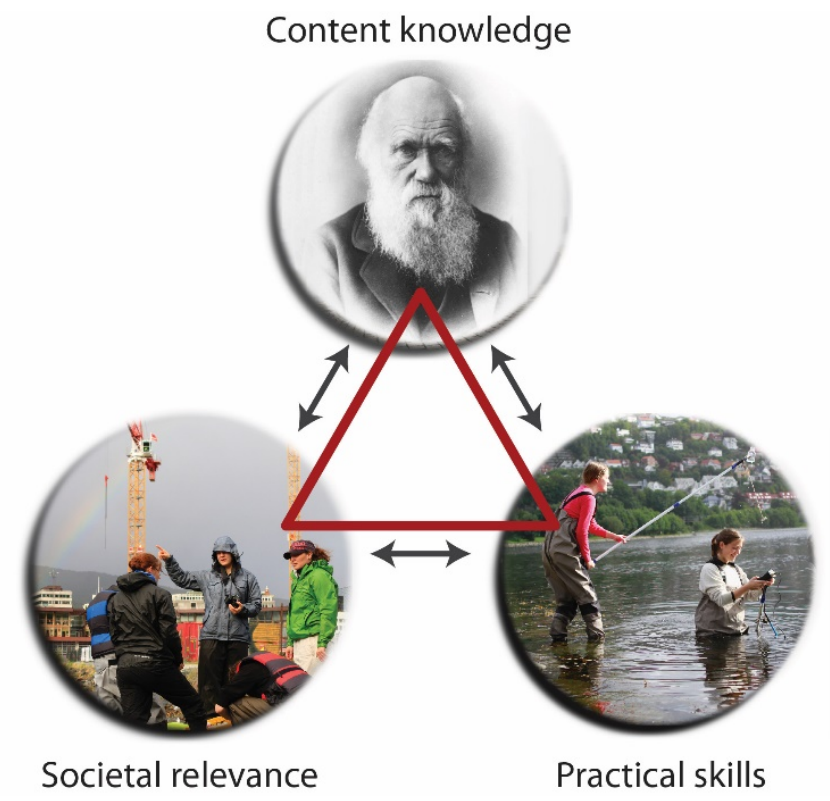

Figure 1. The 'domain of biology' as defined by the interplay between the scientific content knowledge of biology, the various skills and practices that are inherent in biology and society's applications of and needs for biological knowledge and skills.

Once the need to integrate society and workplace in education is identified, the next step is to pinpoint how this should be done. The traditional approach is to treat these issues in a classroom setting, and to lecture about them and possibly include representatives from society and workplaces into classical university courses. A more active learning approach is to facilitate work with real-life problems, such as can be found in Team-Based-Learning or Problem-BasedLearning setting. Work placement courses take the active learning approach one step further as the students spend time at real workplaces and engage in authentic workplace tasks and processes.

When bioCEED suggested a work placement course as part of the BSc program in biology, it was met with some immediate skepticism, particularly from the academic staff. "We are not a vocational college!", "This is a sell-out of the academic culture and standards to the market forces in society!" and "We don't want to dumb down our educations!" were typical comments. There was also concern that the work placement would come at the expense of subject knowledge, as the work placement course would replace an elective course in the curriculum. However, after discussions with students, workplaces and among the academic staff, a trial was 
agreed. A key point in creating support for the trial was to develop intended learning outcomes (ILOs) that did not only emphasize the practical and transferrable skills of the training, but also contributions to deeper learning of biology and to help students internalize their identity as a biologist (See intended learning outcomes in section 3.2).

bioCEED argued that the work placement should be part of the list of elective credit-awarding biology courses that can be included in a biology degree. This requires a course description and ILOs that fulfil the institution requirements, follows procedures for approval and implementation, and provide relevant information for prospective students. The initial course description was developed in close collaboration with the Department of Biology's Education Committee to ensure that the courses was aligned and included in the biology program course portfolio. It was considered essential for student recruitment that work placement courses were part of the ordinary course portfolio. This communicates to the students that the work placement is an approved elective course that can be part in their biology degree and contribute to their knowledge and competences as future biologists.

The main placement course started in the spring semester 2015 with 13 students that could choose among 13 hosts. The unusual nature of the course, the many workplaces involved and the open student blogs (see section 3.4 on reporting and reflecting) created immediate attention, including substantial press coverage. The main business newspaper in Norway, Dagens Næringsliv, wrote a double-page article about the course under their 'career' section, with the heading "Turning the university into vocational training" (Gjerde, 2016). The article was written in a positive tone, yet prompted the Rector of the university to clarify through twitter that "The criticism misses the point!" (Olsen, 2016) assuming that the phrase vocational training implied something problematic or not quite up to university standards. This illustrates how tense the feelings around university identity can be, and how work placements challenge the university identity. Our position in the debate was, on one hand, to point out the effectiveness of the approach and the course in motivating students for learning, and helping them build and connect their academic knowledge and their skills. We also argued that the training offered at the university is vocational, in the sense that our students do end up in workplaces, i.e. vocations, and that we as educational institutions should have high ambitions in shaping tomorrows' workforce.

\subsection{Workplace host recruitment}

One of the first tasks in the development of the course was the range of potential work places and tasks needed. During 2014, 45 institutions near Bergen were invited to be hosts for students in biology. These included private- companies, a wide range of and governmental institutions and NGOs. The institutions were selected because they employ biologists as part of their workforce. The selection was based on word-of-mouth information about previous students' employment, existing collaboration with the university in research or education, publicly available description of the workplace and the relevance of the work at the workplace. In many cases, the link to biology was obvious, for instance teaching biology in upper secondary school or participating in biological research. In other cases, the link was less obvious, such as working for the municipality area management or Bergen Science Center.

In the invitation letter, we described our motivation for developing the course, and potential benefits for students and hosts. For the host, we argued that placement students represent an opportunity to meet potential future employees, to be presented to the wider student cohort in student presentations and blogs, to get short-term access to a free, motivated and knowledgeable workforce, and to build closer contact with the university and education programs. It was a prerequisite that work placement students engage in biology-related tasks during their work placement, receive appropriate training by the host and that health and safety were provided. 
After the initial query, potentially interested hosts were provided with additional information. This consisted of meetings and email correspondence concerning the rights and obligations of hosts and students, duration of placement and the expected skills. The number of active hosts has since varied from 12 to 15 from semester to semester and with a total of 17 different workplaces having been part of the course.

\subsection{Initial course design}

Initially, the program was intended to offer placements at three levels, (1) first-year students spending one day observing biologists in the workforce, (2) first- to second year students working 40 hours at the workplace and (3) second to third year students working 140-200 hours at the workplace. Level 1 was dismissed as it became clear during the early discussions that it was of little interest for the hosts to have students looking over their shoulders, and of limited worth for the students to only observe without actually engaging in the work.

The level 2 work placement was organized as a small course (3 ECTS) so that students could manage to join work placements in addition to an otherwise full-time course progression. This was explicitly requested by the students, but the course was terminated after three semesters. It became clear that while the students were positive to the course, the outcomes were small relative to the time investments required by all parties. It is resource intensive to make formal arrangements and contact between teacher and hosts, enquiries, training and finding time in a full schedule of lectures and compulsory activities. Especially, the hosts found 40 hours help from students to be of limited worth given the initial time needed to train and tutor the students before they could engage in meaningful work. Also, only nine students enrolled during the 3 semesters, which was a quarter of the number enrolled in the level 3 course.

The level 3 work placement course has been running since spring 2015 with about 10 students each semester and a total of 63 students enrolled. The level 3 work placement course is the focus of the rest of the paper.

\section{Contents of the work placement course}

\subsection{Course requirements}

The course is primarily aimed at second- to third year students registered for the BSc in Biology. A few master (MSc) students have also taken the course. From fall 2017, we require the students to have at least 60 ECTS in biology before they can apply for the course (equivalent to about 1.5 to 2 years study). This was decided following discussions with the work placement hosts, and ensure that the hosts are provided with students with a sufficient biology and academic background. After 1.5 years, students have been through courses in philosophy, mathematics, chemistry, evolution, ecology and organismal biology. They have practical biological training from at least two weeks of field courses and four weeks of laboratory courses. After 2.5 years, students have also completed courses in cell biology, comparative physiology, molecular biology, biodiversity, or ecology. The work placement course is part of the biology degree in the portfolio of elective courses.

\subsection{Intended learning outcomes}

According to the ILOs, the placement students must be given biology-relevant tasks, and they must be tutored by a workplace host. The course should help students develop an understanding of how biology and biological competence is used at the workplace and is otherwise present in societal developments. This understanding is advanced through engagement with everyday workplace tasks and activities and also facilitated through a closed Facebook group. On Facebook, the course teachers regularly post and comment on articles from various media 
concerning vacant positions as biologists, political and ethical discussions and other societal issues that have clear link with- and relevance for biology.

The ILOs also states that the students are expected to understand how the practical tasks that they perform relate to their campus-based training. The course teachers assist in establishing this link through discussions with the students during course seminars. Student deliverables consists of two parts: (i) 140 hours of work at the workplace and (ii) the student's reporting of experiences and learning outcomes. The reporting consists of four blog posts, a short reflective essay and a presentation to fellow students and the teachers at the end of the semester. In addition, there are two compulsory seminars with fellow students and course teachers during the semester. The total workload of the course is about 250 hours (10 ECTS), including some hours of commuting to hosts.

\subsection{Student-host-teacher collaboration and communication}

The work placement hosts include a wide variety of workplaces (Table 1), which reflects the students' interests and future working life in that students from disciplinary educations typically end up in a wide range of occupations. All hosts provide a short description of the work placement they offer and specify tasks or projects that the students will engage with. Many hosts offer a variety of projects and tasks (Table 1), a few of which can require specialized competences, hence only available to certain students. After students sign up for the course, they submit a written application. Here, they write a few sentences on their motivation to join the work placement and rank three placement offers. The course teachers pair student and host based on applications and host availability, while special skills that may be required are also taken into account. Most students are placed in their preferred workplace, but may be given their second or third choice if the first choices are occupied. We found it easier to recruit research institutions as hosts, and that students prefer research-related workplaces and the nongovernmental organization, whereas hosts more focused towards education and science communication seem less popular (Table 1).

Table 1. Number of workplaces, projects they have offered and students per sector during the six semesters since the start of the work placement program. Some host institutions have been recruited in later years, and not all hosts have offered placements every semester.

\begin{tabular}{lccc}
\hline Sector & Hosts & Projects & Students \\
\hline Research institution & 7 & 30 & 40 \\
Non-governmental organization & 1 & 3 & 6 \\
Governmental agency & 2 & 7 & 5 \\
Industry & 1 & 1 & 1 \\
Educational sector & 2 & 3 & 4 \\
Science communication to the general public & 4 & 12 & 7 \\
\hline
\end{tabular}

At the beginning of the semester, the teachers meet with the students and provide general information about the course as well as specific information about each host. The hosts and the students then receive a letter with practical information, including their respective rights and obligations, assessment criteria, insurance and how to deal with communication or cooperation problems. The student and the host institution are asked to read and sign this document together. From then on, students and hosts agree on when to meet and how to schedule the hours. The teachers generally do not interfere with the student-host interactions.

The students are required to work at least 140 hours at the workplace, to adhere to appointments made with the host, and to be respectful to co-workers. This means that students are given responsibility at the outset to keep track of their hours, scheduling the work placement to fit the 
hosts' needs and the students' commitments at campus. Most students have a normal study progression, including the work placement course and other university courses. This implies that the students are responsible for scheduling the work placement to not conflict with teaching activities in courses they take in parallel.

The hosts are contacted by e-mail or phone at around mid-term to enquire how the students are progressing and if the students are fulfilling their obligations. At this time, the students and course teachers also meet in a seminar. The students are then asked to outline what they have done up to that point during their work placement. They also discuss aspects related to the learning that takes place in work placements; surprises, challenges, whether they have developed new competencies, or if they find that some competencies are lacking. The seminar offers an opportunity for the students to reflect on their experiences together. A major role of the teachers during the seminar is to connect the students' activities at the workplace to biological theory and to a broader understanding of biology and working as a biologist. The teachers also check that the tasks the students are given at the workplace are indeed related to biology.

\subsection{Reporting and reflecting: essay and blog}

The reporting activities are designed to ensure that the students discuss their learning and their own conception of activities, rather than only detailing the procedures that they have performed. This requires careful attention from the teachers, as the students' instincts are to focus on laboratory- or other technical procedures rather than on their own reflection and learning. The task description has therefore increased in detail over the years, with strengthening emphasis on learning and students' thoughts about what they have experienced. In the blogs, students are asked to use pictures and write not only about what they do but focus on their perspectives on their role as biologist and thoughts about working practices. Fellow students are encouraged to read and comment on the blog posts. All blogs are publicly available at https://biopraksis.b.uib.no

The reflective essay is written at the end of the work placement. In the essay, the students can elaborate on the information from the blog-posts. The essay is submitted to the course teachers only, and is not publicly available. This implies that there is a lower threshold to be more open in comparison to the blogs, and room to share any critique the students might have of the course, their own performance, or the work placement host or tasks. The students also write about their learning during the workplace practice, and how the course has helped them develop new perspectives on biology as a discipline and how it interacts with society.

Finally, the students give an open oral presentation in a student seminar at the end of the semester. The presentations focus on introducing the host, describing the work performed and sharing experiences and learning outcomes. There is room for questions and discussions during the presentations.

Students' reports are assessed and given feedback and the course is graded as pass or fail. In cases where students' reports fail, the students are given one additional chance to improve the relevant part of the reporting. Feedback consists of a written note outlining strengths and weaknesses of the students' blogs, essay and presentation.

\subsection{Development progress and course evaluation}

The course has developed over the six semesters it has been running (Figure 2). The development is based on our experience as biologists and teachers, discussions with pedagogical scientists and feedback from students and the workplace hosts. It is interesting to note that all stakeholders (students, hosts and teachers) have instigated changes. The inclusion 
of students, hosts and teachers in the course development has the potential to motivate all parts, and to ensure relevance in the enactment of the course.

2014-07 2015-01 2015-07 2016-01 2016-07 2017-01 2017-07

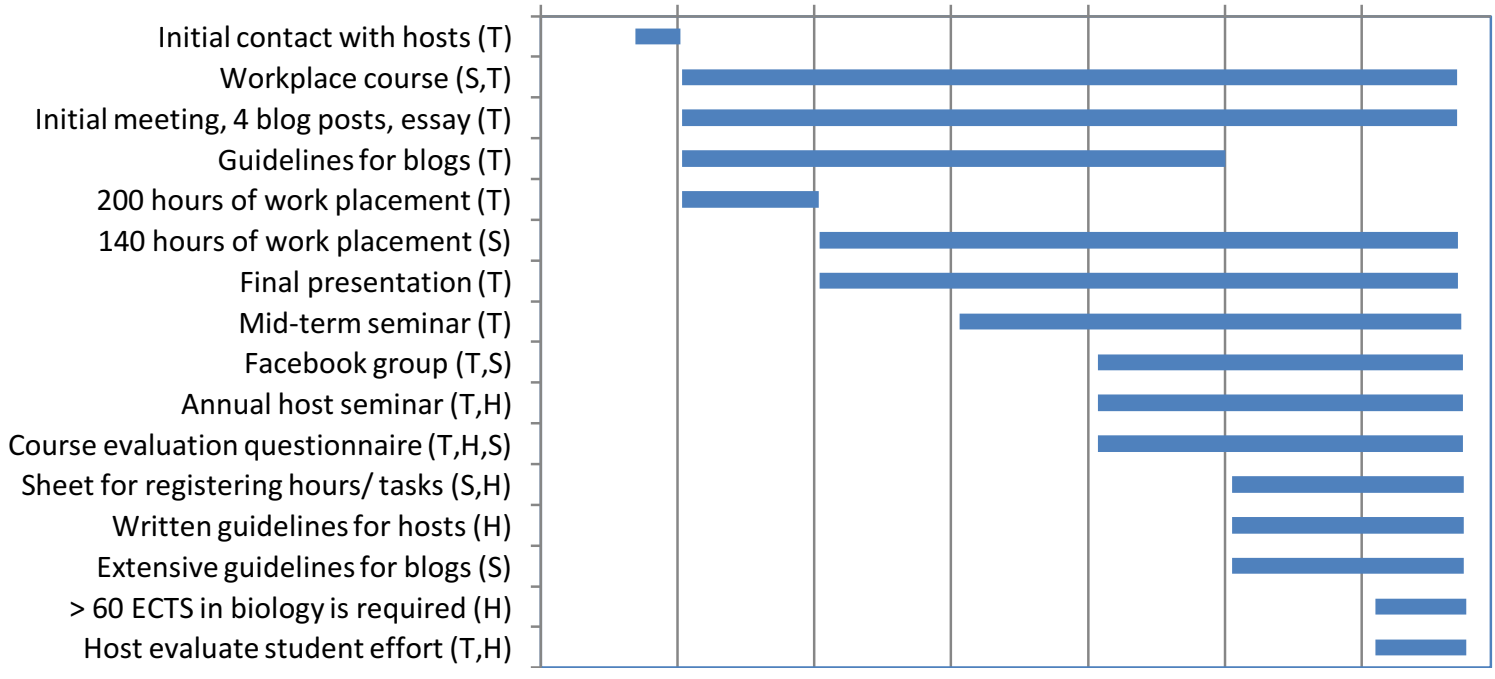

Figure 2. Overview of course development through time. T, S, H indicates initiatives advanced by teachers, students and hosts, respectively.

A course evaluation using a written questionnaire was introduced from fall 2016, meaning only students from that semester has had opportunity to participate in the evaluation to date. The students are generally positive to all aspects of the course, and give the course a high overall score (Table 2). The students are particularly satisfied with the Facebook page communication, the competence of the hosts and the practical skills they acquire. Our experience indicates that students that have been given less biology-relevant assignments during their work placement are less satisfied with the course, highlighting the need to communicate clear expectations to the hosts about work relevance.

Table 2. Summary of the bio298 evaluations from fall 2016 to spring 2017.

\begin{tabular}{llll}
\hline Question & mean & sd & median \\
\hline To what extent did you find the mid-term meeting useful? & 5.1 & 1.9 & 6 \\
To what degree did you find the Facebook page useful? & 6.1 & 0.7 & 6 \\
To what degree did the hosts have high biological competency? & 6.1 & 1.5 & 7 \\
To what degree did you have sufficient time with the host? & 5.5 & 1.5 & 6 \\
To what degree has the work placement given you contacts for future career? & 4.9 & 1.5 & 5 \\
To what degree has the work placements contributed to practical competency? & 5.9 & 1.4 & 6 \\
Has the workload corresponded to 10 ECTs? & 4.4 & 0.9 & 4 \\
All in all, how content are you with the course? & 6.3 & 1.3 & 7 \\
\hline
\end{tabular}

$\mathrm{n}=15$, range $=1$ (worst) to 7 (best)

\section{Discussion}

\subsection{Assessment strategies}

Our hosts represented a broad range of potential workplaces for biologists. While this allows us to offer a broad range of workplace experiences and interesting variation between students within a cohort, this was a challenge for creating an overall assessment and reflection strategy that captures experiences in all the different workplaces. The hosts have varied educational and 
biological competencies and have varied workplace tasks. This at implies that we cannot give the hosts responsibility for formally assessing or grading students. Also, course teachers are not present at the workplace. As a recent development, we now ask the hosts to give feedback on the students' efforts during the work placement. This implies that, neither teachers nor hosts assess the quality of the work that the students perform, which is why the course is graded as a pass-fail. Instead, the students are given responsibility to communicate with their host to ensure that the work they perform is satisfactory.

Literature on workplace learning often warns about a tension between what students learn at campus and what they work with in working life (Korthagan and Kessels, 1999, Schön, 1987). As such, the inclusion of diverse workplaces and dissemination through blogs can be one way to accommodate these challenges, by detailing practices that students engage with and how it connects to their biology training. In addition, in the seminars, the student presentations and through the Facebook group, the course teachers emphasize the link between all the students' varied workplace activities and their training at campus. Each student therefore is exposed to a wide range of workplace opportunities and challenges through the experiences and reflections of their peers. The nature of undergraduate biology work placements is different than in the more cohesive school teacher placement and other professional programs because the assessment has to be more flexible. In many professional programs, workplace hosts are especially trained to supervise students.

Our experience on blogs for assessing the students echo other studies suggesting that blogs can enable student reflections and learning (Cakir, 2013). As the blog guidelines have improved, students are more consistently writing not only about practical matters but also about their learning and their thoughts about future careers. The blogs serve at least five purposes. Firstly, despite the diverse circumstances and relatively sparse interaction with students during their placements, the blogs allow course teachers to monitor the student activity and learning. Secondly, the workplace course aims to foster awareness of competences and the students' understanding of their role as biologists. The students write about these matters and this information is then afforded to other students. Thirdly, it provides training in writing in an emerging genre. Fourthly, they give the students opportunity to follow and learn from each other's experiences. Finally, the blogs allow the students experiences in communicating effectively with a wider readership. The blogs are read approximately 5000 times (i.e., unique hits) each semester.

\subsection{Recognizing the importance of diverse expressions of knowledge}

Many biologists in the workforce combine practical problem solving with in-depth content knowledge about natural phenomena (Blickley et al., 2013). Hence, training that combines theory and practical tasks should also be highly relevant for biology students. Students show a preference for research-related workplaces, which suggests the students favor workplaces that focus on skills that are more similar to skills acquired in previous training. While we can expect that students also develop research competencies through a bachelor thesis, the workplace course offers additional learning outcomes. First, students that undertake a bachelor thesis without a work placement would miss knowledge about how biology and biological competence are used at workplaces and otherwise in society. Second, an important aim of the work placement course has been to highlight that also non-biological skills and competences are essential parts of their training that will be important when the students enter the working force.

It seems that students are generally made aware of the importance of core skills and competences in their discipline. However, some lack understanding of why they should invest in learning of other subjects or transferable skills since these are seldom emphasized during 
courses, in course evaluations or in academic diplomas (Hyland and Johnson, 1998). The importance of also acquiring non-biological competences during higher education was highlighted from results in a survey of 229 biologists in the work-force (Hole et al., 2016). Here, the respondents were asked to rate the relative importance of expertise of biologists entering the working force. Interestingly, approximately $40 \%$ rated biological expertise to be more important, $20 \%$ rated general academic and transferrable skills to be more important, while $40 \%$ rated both to be equally important (Hole et al., 2016).

The students may lack insight that they indeed have developed some important non-biological competences during their education. This was suggested in the national survey on student perceptions on the quality of study programs in Norway (NOKUT, 2014). Since employers seem to value transferrable skills more than educators do (Hole et al., 2016, Ryssevik et al., 2011), unawareness of their own full competence and potential may hamper newly graduated students in their search for relevant and fulfilling jobs. We have experienced that many students in the work placement course, both in blogs, in the course evaluations and seminars, emphasize how the course has made them aware of the importance of such non-biological skills and competences.

\subsection{Prospects}

A possible next step after three years of experience with the placement course is to implement practice training as a compulsory part of the BSc in Biology. The work placement course or one of the similar courses providing research practice or dissemination practice, would then be a program requirement in the BSc degree in biology. A decision to fully integrate such courses in the compulsory program curricula will further strengthen the institutional commitment and acknowledgment of providing students with active learning experiences and training in an authentic biology setting.

\section{Conclusions}

This paper has provided an overview of visions, background and execution of an innovative course in biology. By collaborating with research institutions, the private sector, public sector and NGOs, we have found that students can be given high-impact authentic learning experiences that can complement and add to their training at campus. The integration of work placements into a disciplinary course also bears some consideration of university culture, as these advances can meet with controversy. Grounding new course developments into the organization can require considerable effort to ensure common visions and strategies.

Based on our experiences and feedback from students and hosts, we think other disciplinary programs may benefit from including work placements. Especially, the student presentations, blog entries and discussions during seminars suggests that the students have a steep learning curve during the work placement, both of biological skills, transferrable and in terms of personal development.

Research on students' learning and impact of work placements will be beneficial in developing even more research-based and effective teaching practices. A next natural step is to perform a thorough assessment of the impact of work placements as part of discipline-oriented education programs. That is, assessing impact on student motivation, learning outcome, study progression and employment. New developments in work placements training require sharing and dissemination beyond this paper.

\section{Acknowledgements}


We would like to thank the Department of Biology, UiB, and the following people for valuable discussions and suggestions: All work placement course students and hosts over the years, Pernille Bronken Eidesen, Øyvind Fiksen, Kristin Holtermann, Lucas Jeno, Tom Klepaker, Gro van der Meeren and Arild Raaheim. The development of the workplace practice course and this paper was supported by The Centre of Excellence in Biology Education (bioCEED) and the project "How implementation of practice can improve relevance and quality in discipline and professional educations" (PRIME) financed by the Norwegian Research Council FINNUT program (project 238043).

\section{References}

Abbott, A. D. (1988). The system of professions : an essay on the division of expert labor. Chicago \& London: University of Chicago Press.

Aldas, T., Crispo, V., Johnson, N. and Price, T. A. (2010). Learning by Doing: The Wagner Plan from Classroom to Career. Peer Review 12(4) 24-28.

Bennett, N., Dunne, E. and Carre, C. (1999). Patterns of core and generic skill provision in higher education. Higher Education 37(1) 71-93.

Billett, S. (2009). Realising the educational worth of integrating work experiences in higher education. Studies in Higher Education 34(7) 827-843.

Blickley, J. L., Deiner, K., Garbach, K., Lacher, I., Meek, M. H., Porensky, L. M., Wilkerson, M. L., Winford, E. M. and Schwartz, M. W. (2013). Graduate Student's Guide to Necessary Skills for Nonacademic Conservation Careers. Conservation Biology 27(1) 24-34.

Bogo, M. (2006). Field Instruction in Social Work. The Clinical Supervisor 24(1-2) 163-193.

Cakir, H. (2013). Use of blogs in pre-service teacher education to improve student engagement. Computers \& Education 68 244-252.

Dewey, J. (2011). Democracy and Education. Hollywood: Simon \& Brown.

Dreyfus, H. L. and Dreyfus, S. E. (1986). Mind over machine: the power of human intuition and expertise in the era of the computer. New York: Free Press.

Edwards, H., Smith, S., Courtney, M., Finlayson, K. and Chapman, H. (2004). The impact of clinical placement location on nursing students' competence and preparedness for practice. Nurse Educ Today 24(4) 248-255.

Freeman, S., Eddy, S. L., McDonough, M., Smith, M. K., Okoroafor, N., Jordt, H. and Wenderoth, M. P. (2014). Active learning increases student performance in science, engineering, and mathematics. Proceedings of the National Academy of Sciences 111(23) 84108415 .

Gardner, J. and Belland, B. R. (2012). A Conceptual Framework for Organizing Active Learning Experiences in Biology Instruction. Journal of Science Education and Technology $21(4) 465-475$.

Gjerde, A. S. (2016). Gjør biologistudenter til yrkesfagelever. Dagens Nceringsliv. 
Hole, T. N., Jeno, L. M., Holtermann, K., Raaheim, A., Velle, G., Simonelli, A. L. and Vandvik, V. (2016). bioCEED Survey 2015. Retrieved from University of Bergen, BORA - Bergen Open Research Archive: http://hdl.handle.net/1956/11952 78 pp.

Hyland, T. and Johnson, S. (1998). Of Cabbages and Key Skills: exploding the mythology of core transferable skills in post - school education. Journal of Further and Higher Education 22(2) 163-172.

Kennedy, M., Billett, S., Gherardi, S. and Grealish, L. (2015). Practice-based learning in higher education: jostling cultures. New York, NY: Springer Berlin Heidelberg.

Korthagan, F. and Kessels, J. (1999). Linking theory and practice: Changing the pedagogy of teacher education. Educational Researcher 28(4) 4-17.

Kyndt, E., Dochy, F., Struyven, K. and Cascallar, E. (2011). The direct and indirect effect of motivation for learning on students' approaches to learning through the perceptions of workload and task complexity. Higher Education Research \& Development 30(2) 135-150.

Matthew, S. M., Taylor, R. M. and Ellis, R. A. (2012). Relationships between students' experiences of learning in an undergraduate internship programme and new graduates' experiences of professional practice. Higher Education 64(4) 529-542.

NOKUT (2014). The Norwegian Agency for Quality Assurance in Education www.studiebarometeret.no.

Næss, T., Thune, T., Støren, L. A. and Vabø, A. (2012). Samarbeid med arbeidslivet i studietiden. Omfang, typer og nytte av samarbeid. STEPOECD (2010-2011) AHELO: Assessment of higher education learning outcomes. Oslo: NIFU Skriftserie.

Olsen, D. R. (2016). Re: «fremragende utdannelse»@UiB ble til yrkesskole,skriver@DN_no Men kritikken treffer ikke http://www.dn.no/talent/2016/02/18/2145/Utdannelse/gjrbiologistudenter-til-yrkesfagelever ...@evagrinde @sfubioceed. February 16. Available at: https://twitter.com/UiBrector_Olsen/status/700577694422007808.

Polanyi, M. (1967). The tacit dimension. Garden City, NY: Doubleday Anchor.

Regjeringen, ed. (2014). Long-term plan for research and higher education 2015-2024. Oslo, The Norwegian Ministry of Education.

Regjeringen, ed. (2017). Kultur for kvalitet i høyere utdanning (Culture for quality in higher education). Oslo, The Norwegian Ministry of Education.

Ryssevik, J., Høgestøl, A., Dahle, M. and Holthe, I. C. (2011). Kompetanse 2020 Universitetsutdanningenes synlighet og relevans og samfunnets behov. Bergen, IDEAS2EVIDENCE Rapport 4 / 2011. 208 pp.

Scholz, R. W., Steiner, R. and Hansmann, R. (2004). Role of internship in higher education in environmental sciences. Journal of Research in Science Teaching 41(1) 24-46.

Schön, D. A. (1987). Educating the Reflective Practitioner. San Fransisco: Jossey Bass Publ.

Simons, L., Fehr, L., Blank, N., Connell, H., Georganas, D., Fernandez, D. and Peterson, V. (2012). Lessons Learned from Experiential Learning: What Do Students Learn from a 
Practicum/ Internship. International Journal of Teaching and Learning in Higher Education 24(3) 325-334.

Singer, S. R., Nielsen, N. R. and Schweingruber, H. A. (2013). Biology Education Research: Lessons and Future Directions. CBE-Life Sciences Education 12(2) 129-132.

UiB (2017). Kvalitet i utdanning. Handlingsplan 2017-2022 (Quality in education. Action plan 2017-2022). University of Bergen.

Wurdinger, S. and Carlson, J. (2009). Teaching for Experiential Learning: Five Approaches That Work. New York, NY, United States: Rowman \& Littlefield Education. 